\title{
Alkalotolerant and Alkalophilic Bacteria in Seawater
}

\author{
M. Maeda and N. Taga \\ Ocean Research Institute, University of Tokyo, Minamidai, Nakano, Tokyo 164, Japan
}

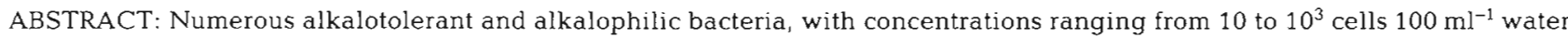
sample, were isolated from seawater in the Pacific and Indian Oceans using a buffered medium of $\mathrm{pH} 10.6$. The $\mathrm{pH}$ effects on growth rates were used to define the occurrence of three types of alkalotolerant and alkalophilic bacterial groups: (1) bacteria exhibiting high growth rates throughout the $\mathrm{pH}$ range of 7.3 to $10.6 ;(2)$ bacteria growing well at $\mathrm{pH} 9$ and below, but to a lesser extent also at $\mathrm{pH} 10.6$; (3) bacteria which grow only at $\mathrm{pH} 10$ to 10.6. Isolates of Type (1) are more abundant than those of the other two groups. Types (1) and (2) are tentatively named alkalotolerant; Type (3), alkalophilic. In the alkaline medium, $\mathrm{pH}$ fluctuation during growth was not observed, probably due to the buffer action of $\mathrm{Na}_{2} \mathrm{CO}_{3}$ added to the medium. The alkalotolerant bacteria isolated from the Pacific Ocean consisted of Pseudomonas spp.; those isolated from Sagami Bay were Vibrio and Pseudomonas spp.; these species are common in the water area investigated.
\end{abstract}

\section{INTRODUCTION}

It has generally been assumed that most bacterial species grow best in media with relatively restricted $\mathrm{pH}$ ranges, i. e. close to neutrality. This would be in line with the situation in natural ecosystems which usually feature neutral $\mathrm{pH}$ conditions, except in extreme environments. However, even in normally neutral environments, wide fluctuations of $\mathrm{pH}$ are often observed. Rapid growth of phytoplankton, for example, can cause the environmental $\mathrm{pH}$ to increase temporarily to more than 10 , even in seawater. Under such circumstances, certain bacterial populations may become subject to rapid $\mathrm{pH}$ fluctuations. Hitherto, the question has remained unanswered whether or not these bacteria represent particular strains or are common members of the local ecosystem.

While there are several reports concerning the occurrence of alkaline bacteria in terrestrial soil and fresh water, this paper is the first assessment of the distribution of alkaline bacteria in the marine environment. The generic composition of the bacteria isolated and their growth versus $\mathrm{pH}$ fluctuations have been determined. The bacteria concerned are Pseudomonas spp. and Vibrio spp., isolated from the Pacific Ocean and from Sagami Bay, Japan.

\section{MATERLALS AND METHODS}

\section{Water Samples}

Seawater samples were collected using a sterilized ORIT sampler (Taga, 1968) at the stations shown in Figure 1. Seawater temperatures at different water depths were measured using protected reversing thermometers attached to the Nansen Bottles.

\section{Media}

The composition of the alkaline medium for the growth of alkaline bacteria (alkalotolerant and alkalophilic) was as follows (g) : $\mathrm{NaCl}, 18.0 ; \mathrm{KCl}_{t} 0.6$; $\mathrm{MgCl}_{2} \cdot 6 \mathrm{H}_{2} \mathrm{O}, 8.1 ; \mathrm{CaCl}_{2}, 0.8$; Bacto-peptone, 1.5; Bacto-soytone, 1.5; Bacto-yeast extract, 1 ; ferric citrate, 0.1 ; agar, $15 ; \mathrm{Na}_{2} \mathrm{CO}_{3}, 10 ; 1000 \mathrm{ml}$ distilled water. $\mathrm{Na}_{2} \mathrm{CO}_{3}$ was sterilized separately and added to the other components after cooling to $50^{\circ} \mathrm{C}$. This gave the medium a pH of 10.6 and a $\mathrm{Na}^{+1}$ concentration of about $0.4 \mathrm{M}$. For media of $\mathrm{pH} 7.3,8.0,9.0$ and 10.0, the amount of $\mathrm{Na}_{2} \mathrm{CO}_{3}$ added to the basic medium was $0.07,0.15,0.42$ and $2.35 \mathrm{~g} \mathrm{l}^{-1}$, respectively.

The composition of the medium for heterotrophic 


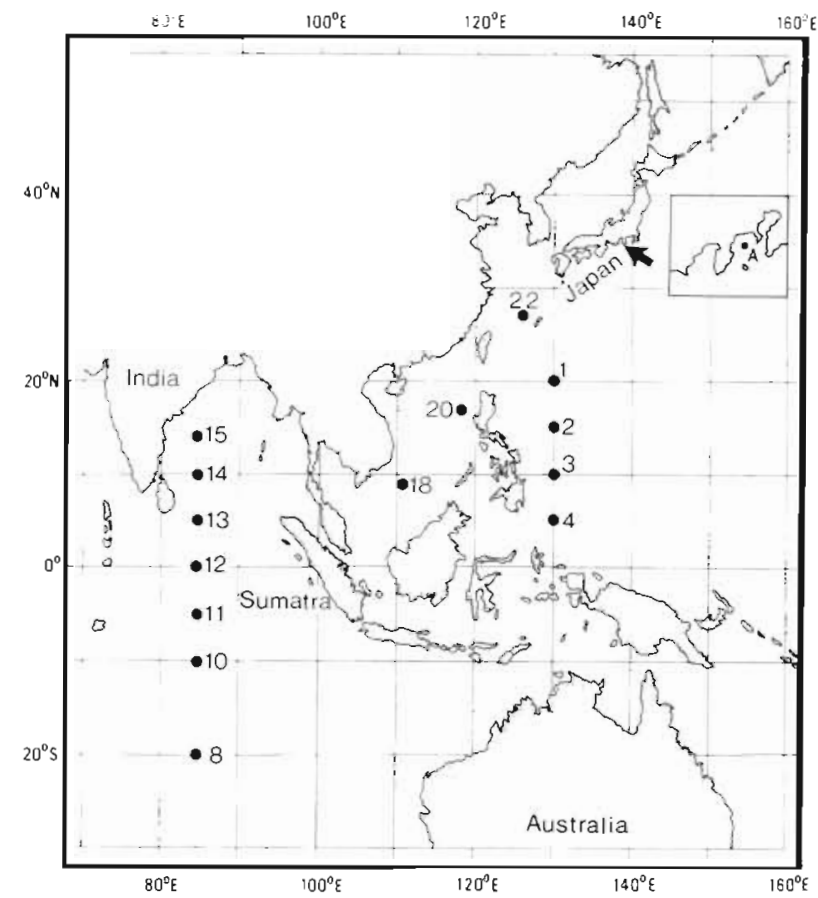

Fig. 1. Stations for seawater sampling

bacteria was as follows (g): Bacto-peptone, 2; Proteosepeptone No. 3, 1; Bacto-soytone, 1; Bacto-yeast extract, 1 ; ferric citrate, 0.1 ; agar, $15,1000 \mathrm{ml}$ seawater. $\mathrm{pH}$ was adjusted to 7.4 .

\section{Estimation of Bacterial Number}

A suitable volume of seawater was filtered through a sterilized Nuclepore filter $(0.2 \mu \mathrm{m}$ pore size; $47 \mathrm{~mm}$ diameter) and the filters were placed on plates of alkaline medium or the medium for heterotrophic bacteria mentioned above. All plates were incubated at $20^{\circ} \mathrm{C}$ for 2 weeks before the bacterial colonies were counted. Bacteria were isolated for further study by picking all colonies from a suitable plate and by transferring them to fresh medium for purification and storage.

Bacterial numbers in the samples are defined as the number of colony forming units (c. f. u.) per $100 \mathrm{ml}$ of seawater.

\section{Identification of Bacteria}

The generic composition of the isolates, especially the alkalotolerant bacteria, was determined according to the scheme of Shewan et al. (1960). The vibriostatic compound $\quad 0 / 129$ (2,4-diamino-6,7-diiso-prophylpteridine) was not used as means to distinguish Vibrio from Aeromonas. These were identified on the basis of differences in gas production using glucose as the substrate. The mode of glucose metabolism of the isolates was determined using Hugh-Leifson's medium (1953) based on artificial seawater.

Alkalophilic bacteria which grew only in the medium of $\mathrm{pH} 10$ and above were not identified because of the difficulty in working under high $\mathrm{pH}$ conditions during the identification procedure.

\section{Determination of Bacterial Growth}

Alkalotolerant and alkalophilic bacteria were preincubated in the $\mathrm{pH} 8$ medium for $2 \mathrm{~d}$ and in the $\mathrm{pH}$ 10.6 medium for $7 \mathrm{~d}$ respectively; $0.5 \mathrm{ml}$ of the preincubated culture was then used to inoculate $50 \mathrm{ml}$ of Iiquid medium. After a suitable incubation period $-2 \mathrm{~d}$ for the alkalotolerants and $7 \mathrm{~d}$ for the alkalophilic bacteria - the bacterial cells were centrifuged and washed three times with $3 \%(\mathrm{w} / \mathrm{v}) \mathrm{NaCl}$. The amount of bacteria in the centrifuge tube was measured in terms of protein concentration determined by the method of Lowry et al. (1951).

\section{RESULTS}

A large number of the bacterial cells present in the seawater samples were able to grow in the alkaline medium ( $\mathrm{pH}$ 10.6). The numbers of these microbes

Table 1. Generic composition of alkaline (alkalotolerant and alkalophilic) bacteria from the Pacific Ocean and Sagami Bay and their growth as a function of $\mathrm{pH}$

\begin{tabular}{|c|c|c|c|c|c|c|}
\hline \multirow{2}{*}{$\begin{array}{c}\text { Strain } \\
\text { No. }\end{array}$} & \multirow[t]{2}{*}{ Genus } & \multicolumn{5}{|c|}{$\mathrm{pH}$} \\
\hline & & 7.3 & 8.0 & 9.0 & 10.0 & 10.6 \\
\hline P 1 & Pseudomonas & 2 & 2 & 2 & 2 & 2 \\
\hline P 2 & Pseudomonas & 2 & 2 & 2 & 2 & 2 \\
\hline P 3 & Pseudomonas & 2 & 2 & 2 & 2 & 2 \\
\hline P 5 & not identified & 0 & 0 & 0 & 1 & 1 \\
\hline P 6 & Pseudomonas & 2 & 2 & 2 & 2 & 1 \\
\hline P 7 & $P_{\text {seudomonas }}$ & 2 & 2 & 2 & 1 & 1 \\
\hline P 8 & Pseudomonas & 2 & 2 & 2 & 2 & 2 \\
\hline P 9 & Pseudomonas & 2 & 2 & 2 & 2 & 2 \\
\hline P 16 & Pseudomonas & 2 & 2 & 2 & 2 & 1 \\
\hline P 25 & not identified & 0 & 0 & 0 & 2 & 2 \\
\hline S 1 & Vibrio & 2 & 2 & 2 & 1 & 1 \\
\hline S 3 & Pseudomonas & 1 & 1 & 1 & 1 & 1 \\
\hline S 4 & Pseudomonas & 2 & 2 & 2 & 2 & 2 \\
\hline S 5 & Pseudomonas & 2 & 2 & 2 & 2 & 2 \\
\hline S 6 & Vibrio & 2 & 2 & 2 & 2 & 2 \\
\hline S 7 & Vibrio & 2 & 2 & 2 & 2 & 2 \\
\hline S 15 & not identified & 0 & 0 & 0 & 1 & 1 \\
\hline \multicolumn{7}{|c|}{ P: collected in the Pacific Ocean. } \\
\hline \multicolumn{7}{|c|}{ S: collected in Sagami Bay. } \\
\hline \multicolumn{7}{|c|}{ 1. colony diameter below $5 \mathrm{~mm}$. } \\
\hline \multicolumn{7}{|c|}{ 2: colony diameter above $5 \mathrm{~mm}$. } \\
\hline
\end{tabular}


ranged from 10 to $10^{3} 100 \mathrm{ml}^{-1}$ in the upper layers to less than $10^{2} 100 \mathrm{ml}^{-1}$ in the lower layers of the profile (Fig. 2). The results also show that, at most depths, alkaline bacteria formed a relatively constant proportion of the heterotrophic bacterial population.

The growth of bacterial strains, P 2, P 3, P 5, P 6, P 7 and $P 25$, versus various $p H$ values are shown in Table 1. The following tentative grades of growth were adopted: 1 indicates colonies with diameters below 5 $\mathrm{mm}$; and 2, colonies above $5 \mathrm{~mm}$ diameter, after 2 weeks incubation on the 5 agar media of different $\mathrm{pH}$. Three types of growth patterns can be distinguished: (1) bacteria producing high yields throughout the $\mathrm{pH}$ range of 7.3 to 10.6 , even if their optimum $\mathrm{pH}$ was near $7_{\text {; }}$ (2) bacteria growing well at $\mathrm{pH} 9$ and below, but which can also grow at $\mathrm{pH} 10$ and 10.6 though to a lesser degree; (3) bacteria which only grow at $\mathrm{pH} 10$ to 10.6. These three growth patterns were also recogniz-

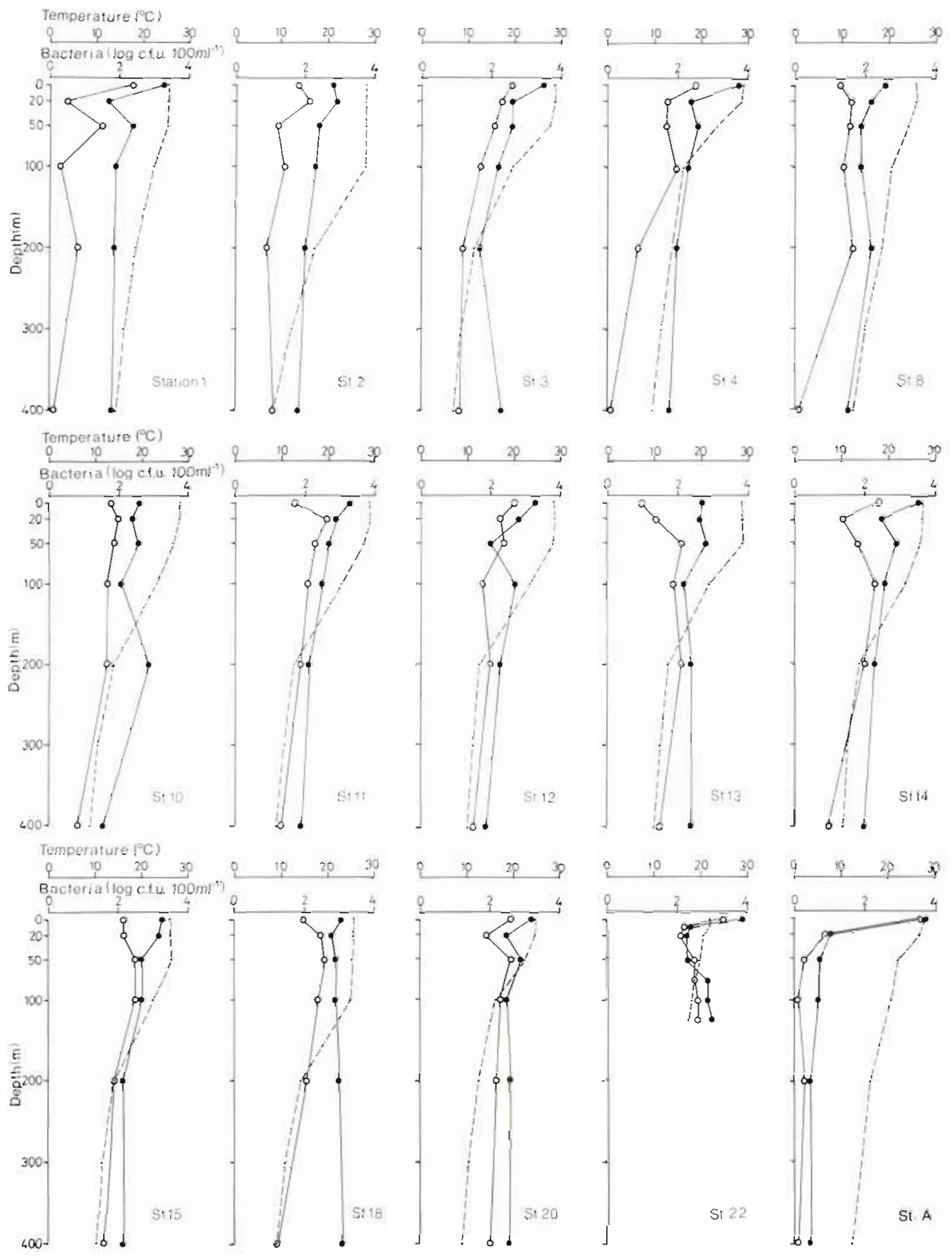

Fig. 2. Profiles of heterotrophic and alkaline (alkalotolerant and alkalophilic) bacteria in seawater. (O) alkaline bacteria; (•) heterotrophic bacteria; broken line: water temperature 


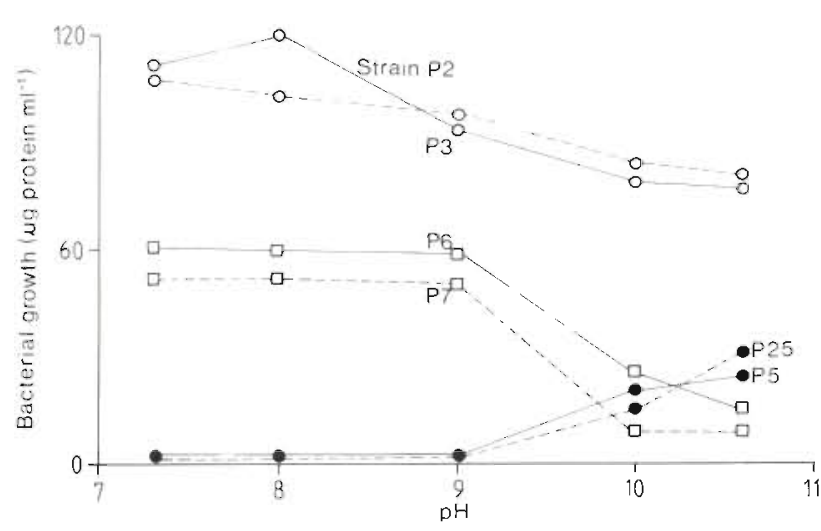

Fig. 3. Bacterial growth as a function of $\mathrm{pH}$

able when the strains were cultivated in the liquid medium with various $\mathrm{pH}$ values (Fig. 3). We call Types (1) and (2) 'alkalotolerant', and Type (3) 'alkalophilic' bacteria. The isolates belonging to Type (1) were more abundant as compared to the other two groups. In the culture liquids, $\mathrm{pH}$ fluctuations were not observed during growth, probably because of the strong buffer action of $\mathrm{Na}_{2} \mathrm{CO}_{3}$.

Table 1 shows the generic composition of alkalotolerant bacteria in the samples. The isolates from the Pacific Ocean (Stations 1 and 4) were identified as Pseudomonas spp., those from Sagami Bay as Pseudomonas spp. and as Vibrio spp., respectively.

\section{DISCUSSION}

We found an unexpectedly large number of bacteria, isolated from the seawater, that were able to grow in alkaline medium. On reculturing, all isolates grew again in the new alkaline medium. This suggests that these microbes on the agar plate used for isolation do not maintain their metabolism by mutual effects, but are able to maintain their cell metabolism independently in a high alkaline environment.

The results obtained regarding $\mathrm{pH}$ effects on microbial growth show the occurrence of three types of alkalotolerant and alkalophilic bacterial groups as mentioned under 'Results'. Among these groups, alkalophilic bacteria had never been found using the ordinary medium of near neutral $\mathrm{pH}$.

As shown in Table 1, the generic composition of the alkalotolerant microbes consisted of Pseudomonas spp. in the Pacific Ocean and $P_{\text {seudomonas spp. and Vibrio }}$ spp. in Sagami Bay; all these are very common genera in seawater (Sieburth, 1971; Simidu et al., 1977). The bacteria belonging to Type (1), i. e. those which grow well from $\mathrm{pH} 7.3$ to $\mathrm{pH} 10.6$, are the most abundant of the three groups. These results suggest that the species commonly present in seawater are capable of adapting to rapid environmental change including fluctuations in $\mathrm{pH}$. In contrast, in the terrestrial environment specific forms, such as Bacillus, have been isolated in an alkaline medium (Horikoshi, 1971).

The reason why a substantial number of bacteria in seawater possesses alkalotolerant or alkalophilic characteristics requires further investigation (the $\mathrm{pH}$ values of all seawater samples collected were less than 8.2). A possible explanation may be the connection between alkaline bacteria and the microenvironment of suspended aggregates, where $\mathrm{NH}_{3}^{+1}$ concentration should be high as the result of bacterial degradation of organic matters. The position of marine bacteria in the microbial evolution processes should also be taken into account. In addition, many of the alkaline bacteria isolated, especially the alkalotolerants, concentrate and accumulate calcium ions from the medium around their cells; this might represent one of the processes of metal-lump formation in the sea.

Acknowledgements. The authors are indebted to Dr. Y. Akagi and Mr. K. Nagao, Ocean Research Institute, University of Tokyo for help in isolating bacteria from water samples. During the cruises in 1978 seawater samples were collected with the cooperation of the officers and crew of $R$. V. 'Hakuhomaru' and 'Tanseimaru', Ocean Research Institute, University of Tokyo.

\section{LITERATURE CITED}

Horikoshi, K. (1971). Production of alkaline enzymes by alkalophilic microorganisms. Part I. Alkaline protease produced by Bacillus No. 221. Agri. Biol. Chem. 35: $1407-1414$

Hugh, R., Leifson, E. (1953). The taxonomic significance of fermentative versus oxidative metabolism of carbohydrates by various Gram-negative bacteria. J. Bact. 66: $24-26$

Lowry, O. H., Rosebrough, N. J., Farr, A. L., Randall, R. J. (1951). Protein measurement with the Folin phenol reagent. J. biol. Chem. 193: 265-275

Shewan, J. M., Hobbs, G., Hodgkiss, W. (1960). A determinative scheme for the identification of certain genera of Gram-negative bacteria with special reference to the Pseudomonadaceae. J. appl. Bact. 23: 379-390

Sieburth, J. McN. (1971). Distribution and activity of oceanic bacteria. Deep Sea Res. 18: 1111-1121

Simidu, U., Kaneko, E., Taga, N. (1977). Microbiological studies of Tokyo Bay. Microb. Ecol. 3: 173-191

Taga, N. (1968). Some ecological aspects of marine bacteria in the Kuroshio Current. Bull. Misaki Mar. Biol. Inst., Kyoto Univ. 12: $65-76$ 